\title{
First record of Necrobia rufipes (De Geer, 1775) (Coleoptera; Cleridae) associated with pet food in Brazil
}

\author{
Gredilha, $R^{\text {a* }}{ }^{\text {and Lima, } A F^{\mathrm{b}}}$ \\ aLaboratório de Diptera, Departamento de Entomologia, Instituto Oswaldo Cruz - FIOCRUZ, \\ Av. Brasil 4365, Manguinhos, CEP 21045-900, Rio de Janeiro, RJ, Brazil \\ 'Laboratório de Entomologia, Departamento de Entomologia e Fitopatologia, Instituto de Biologia, \\ Universidade Federal Rural do Rio de Janeiro, Km 47, CEP 23890-000, Seropédica, RJ, Brazil \\ *e-mail: gredilha@ioc.fiocruz.br
}

Received May 24, 2005 - Accepted August 16, 2005 - Distributed February 28, 2007

The specie Necrobia rufipes is commonly known as the copra beetle in tropical countries and red-legged ham beetle in the United States. According to Nwana, 1993 and Simmons and Ellington (1925) the red-legged ham beetle is a cosmopolitan pest, causing considerable damage to stored commodities such as copra (dried coconut), cheese, dried fish, ham and other products rich in protein content. In India, it is also recorded as a serious pest of cashew nuts (Sengupta et al., 1984).

These beetles can subsist on a diet of copra alone but their development is slow; their diet is almost certainly a supplement by predation on other insects and can promote cannibalism when there is a superpopulation (Ashman 1963). N. rupifes was identified by Carvalho et al. (2000) in a checklist of artropods associated with pig carrion and human corpses in southeastern Brazil. Shalaby et al. (2000) collected N. rufipes from carcasses in contact with soil in Oahu city, Hawaii.

The life cycle varies from 36 to 150 days or more depending on the types of food and temperature. The adult beetle is greenish blue with legs and bases of the antennae reddish brown and it is 3.5 to $7 \mathrm{~mm}$ long (Lambkin \& Khatoon 1990; Odeyemi 1997).

The present study was undertaken to investigate the occurrence of these insects on pet food bags in Rio de Janeiro, Brazil.

The peletes were accomplished after opening sacks which had been wrapped at a factory and distributed for selling in the period of May to November-2003. Six different types of pet food from the total available marks for sale were examined and the insects found were removed and preserved in $70 \%$ ethanol and taken to the Laboratory of Entomology, Universidade Federal Rural do Rio de Janeiro for identification. For ethical reasons, the six types of pet food were identified by code letter.

In the six different selected pet foods the occurrence of $N$. rufipes was observed. 102 specimens were collected. There is no record of these beetles associated with pet food in Brazil.

The occurrence of these beetles reinforces the need to improve the quality of processed food. The origin of infestation is unknown. If can come from raw material or from the place where products are stored.
Table 1. Numbers of Necrobia rufipes collected in different types of pet food during the period of May-November/2003 in Rio de Janeiro-RJ, Brazil.

\begin{tabular}{crrrr}
\hline \multirow{2}{*}{$\begin{array}{c}\text { Types } \\
\text { Pet Food) }\end{array}$} & Larvae & \multicolumn{2}{c}{ Adult } & Total \\
\cline { 3 - 4 } & & Female & Male & \\
\hline A & 13 & 7 & 2 & 22 \\
B & 11 & 6 & 1 & 18 \\
C & 8 & 4 & 1 & 13 \\
D & 10 & 3 & 0 & 13 \\
E & 8 & 4 & 1 & 13 \\
F & 17 & 4 & 2 & 23 \\
Total & 67 & 28 & 7 & 102 \\
\hline
\end{tabular}

\section{References}

ASHMAN, F., 1963. Factors affecting the abundance of the copra beetle, Necrobia rufipes (Deg.) (Col, Cleridae). Bull. Entomol. Res., vol. 53, no. 4, p. 671-680.

CARVALHO, LML, THYSSEN, PJ, LINHARES, AX. and PALHARES, FAB., 2000. A checklist of arthropods associated with pig carrion and human corpses in Southeastern Brazil. Mem. Inst. Oswaldo Cruz., vol. 95, no. 1, p. 135-138.

LAMBKIN, TA. and KHATOON N., 1990. Culture methods for Necrobia rufipes (De Geer) and Dermestes maculatus De Geer (Coleoptera: Cleridae and Dermestidae). J. Stored Prod. Res., vol. 26, p. 59-60.

NWANA, IEA., 1993. Survey of storage coleoptera with attack dried cocoyam chips in Nigeria. J. Stored Prod. Res., vol. 29 , no. 95 , p. 98 .

ODEYEMI, OO., 1997. Interspecific competition between the beetles Dermestes maculatus DeGeer and Necrobia rufipes DeGeer in dried fish. Insect Sci. Applic., vol. 17 , p. 213-220.

SENGUPTA, T., MUKHOPADHYAY, P. and SENGUPTA, R., 1984. Major beetle pest of stored food products in India. Records Zool. Surv. India Occas., vol. 62, p. 65-66.

SHALABY, OA., CARVALHO, LML. and GOFF, ML., 2000. Comparison of patterns of decomposition in hanging carcass and a carcass in contact with soil in a xerophytic habitat on the island of Oahu, Hawaii. J. Forensic. Sci., vol. 45, no. 6, p. $1267-1273$.

SIMMONS, P. and ELLINGTON, GW., 1925. The ham beetle, Necrobia rufipes DeGeer. J. Agric. Res., vol. 30, p. 845-863. 